\title{
Towards the development of safe and commercially viable nickel- iron batteries: improvements to Coulombic efficiency at high iron sulphide electrode formulations
}

\author{
Jorge Omar Gil Posada ${ }^{1}$ (D) Peter J. Hall ${ }^{1}$
}

Received: 10 August 2015/Accepted: 7 December 2015/Published online: 9 January 2016

(C) The Author(s) 2016. This article is published with open access at Springerlink.com

\begin{abstract}
NiFe}$ batteries are emerging as an important energy storage technology but suffer from a hydrogenproducing side reaction which has safety implications and reduces coulombic efficiency. This manuscript describes a systematic improvement approach for the production of $\mathrm{Fe} /$ FeS-based anodes at high concentrations of iron sulphide. Electrodes were made by mixing varying amounts of iron sulphide in such a way that its concentration ranges from between 50 and $100 \%$ (compositions expressed on a PTFE-free basis). Electrode performance was evaluated by cycling our in-house-produced anodes against commercially available nickel electrodes. The results show that anodes produced with larger concentrations outperform their lower concentration counterparts in terms of coulombic efficiency although a slight decrease in the overall cell performance was found when using pure $\mathrm{FeS}$ anodes. At high FeS concentrations a hydrogen-producing side reaction has been virtually eliminated resulting in coulombic efficiencies of over $95 \%$. This has important implications for the safety and commercial development of $\mathrm{NiFe}$ batteries.
\end{abstract}

Jorge Omar Gil Posada

j.o.gil-posada@sheffield.ac.uk

1 Chemical and Biological Engineering, University of Sheffield, Sir Robert Hadfield Building, Mapping Street, Sheffield S1 3JD, UK

\section{Graphical Abstract}

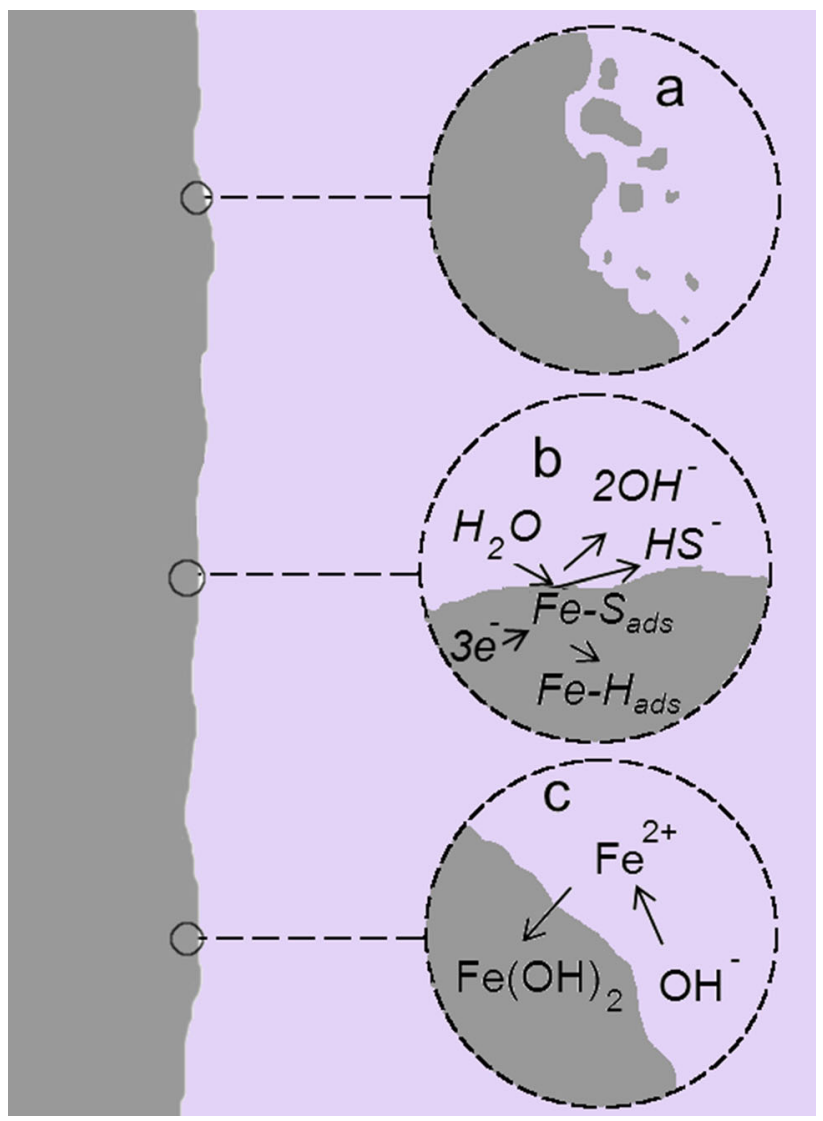

Keywords $\mathrm{FeS}$ anode $\cdot \mathrm{FeS}$ electrode $\cdot \mathrm{NiFe}$ 


\section{Introduction}

Energy storage technologies are now widely accepted as a key class of technologies to stabilize electrical grids with high degrees $(>15-20 \%)$ of renewable generation. In particular, energy storage can reduce the de facto levelized costs of renewable energy by making the energy available when it is most needed - at periods of high demand when electricity has a higher monetary value. In this context, the pioneering energy storage legislation enacted in California provides a fascinating background to monitoring which energy storage technologies will be adopted and where they will be ultimately connected to the grid. The Californian legislation is framed in terms of power (MW) rather than energy (MWh) and makes a clear target to storage connected to the transmission, distribution and individual customers. The 2020 targets are for a total of $1325 \mathrm{MW}$ of storage comprising $700 \mathrm{MW}$ transmission, $425 \mathrm{MW}$ distribution and $200 \mathrm{MW}$ customer connected. The legislation is framed to encourage a diversity of storage solutions and it is clear that storage cost reduction (in MW and MWh) is a major driver. A number of companies have responded to this cost reduction driver, perhaps most notably Aquion, who are manufacturing Aqueous Hybrid Ion Batteries.

One alternative low-cost technology that is receiving increasing attention is the nickel iron battery. $\mathrm{NiFe}$ cells are secondary batteries that were successfully commercialized back in the early 20th century. There are many reasons favouring the use of $\mathrm{NiFe}$ cells as cost-effective solutions to store grid-scale amounts of energy, such as low cost of raw materials, environmental friendliness, electrical abuse tolerance, long life (in the order of thousands cycles of charge and discharge) and compatibility with photovoltaics (PVs). Due to the nature of the heavy metals involved in its construction this technology is suitable for stationary low gravimetric energy applications $\left(30-50 \mathrm{Wh} \mathrm{kg}^{-1}\right)$ [1]. As a consequence, there are good reasons to foresee a largescale utilization of this technology. Due to their outstanding safety properties (zero flammability, fail safe, no over/ under charge), low cost and long lifetime, we anticipate that they will receive widespread public acceptance for customer-connected energy storage.

Although commercially viable, there are still a number of research challenges to further decrease costs and enhance performance. Particularly important are to increase the cell efficiency, preventing electrolyte decomposition and increasing both energy and power densities $[2,3]$.

The main process at the iron electrode (negative electrode) during charging is the reduction of ferrous ion $\left(\mathrm{Fe}^{2+}\right)$ to metallic iron $\left(\mathrm{Fe}^{0}\right)$; in the same manner, the oxidation of metallic iron to ferrous ions takes place during the discharge of the iron electrode. Equation (1) illustrates the charging and discharging (forward and backward reactions, respectively) processes of an iron electrode under alkaline conditions [3, 4].

$\mathrm{Fe}(\mathrm{OH})_{2}+2 e^{-} \leftrightarrow \mathrm{Fe}+2 \mathrm{OH}^{-} \quad \mathrm{E}^{0}-0.87 \mathrm{~V}$

It is well known, however, that during the charging of an iron electrode (under alkaline conditions), water is decomposed to yield hydrogen. Therefore, part of the energy that was originally intended to be stored in the battery is finally wasted in the parasitic evolution of hydrogen. In other words, hydrogen evolution accounts for a drastic reduction in the overall performance of the battery, as indicated by the well-known reaction

$2 \mathrm{H}_{2} \mathrm{O}+2 e^{-} \leftrightarrow \mathrm{H}_{2}+2 \mathrm{OH}^{-} \quad \mathrm{E}^{0}-0.83 \mathrm{~V}$.

Not only does this reaction reduce Coulombic efficiency but it evolves a highly flammable gas with associated safety concerns.

Many attempts have been made in order to mitigate or even prevent the evolution of hydrogen during the charging of the iron electrode. The most promising strategies rely on the modification of the iron electrode formulation, by either nano-structuring the electrode or by the addition of elements (such as sulphur or bismuth) that are capable to increase the overpotential for hydrogen evolution [5, 6]. A completely different approach would consist in the modification of the electrolyte itself by using soluble additives capable of preventing Eq. (2) from happening. With this in mind, different electrolyte additives such as wetting agents [7], long chain thiols [8], organic acids [9], have been investigated [5, 10].

In the quest for a highly efficient NiFe battery, different materials and manufacturing strategies have been used; in fact, nickel-iron cells reaching nearly $800 \mathrm{mAh} \mathrm{g}^{-1}$ have been reported [11, 12]. These batteries require costly reactants and nano-structuring techniques. These aspects would certainly influence the final price of the battery thus produced $[11,12]$.

Recently, pure iron sulphide electrodes were reported as anode alternatives worth taking seriously [13-15]. In our previous research, we have been exploring $\mathrm{Fe} / \mathrm{FeS}$-based anodes in the region of low composition of FeS [16, 17]; this manuscript goes beyond and answers what happens when the concentration of iron sulphide exceeds $50 \%$.

We make use of standard experimental design and multivariate analysis to facilitate our research as with previous publications $[6,16,17]$.

\section{Experimental}

Iron-based electrodes were produced by coating strips of nickel foam with an $\mathrm{Fe} / \mathrm{FeS}$-active paste which consists of varying amounts of electroactive material (with this term 
we mean iron) with a mixture of iron sulphide and PTFE (acting as a binder). The chemicals and materials used to develop our electrode formulations were of the following specifications.

- Iron powder (purity $99.5 \%,<10 \mu \mathrm{m}$ ) from Alfa Aesar

- Iron sulphide (purity $99.5 \%$ ) from Sigma Aldrich

- PTFE (Teflon 30-N, $59.95 \%$ solids) from Alfa Aesar

- Nickel foam (purity $99.0 \%$, density $350 \mathrm{~g} \mathrm{~m}^{-2}$ ) from Sigma Aldrich

Essentially, strips of nickel foam $(10 \times 40 \times 1.8 \mathrm{~mm})$ were coated and then vacuum dried for at least $5 \mathrm{~h}$ until a constant amount of electroactive material (iron) was loaded onto the electrode; this coating process was repeated until approximately $0.2-0.25 \mathrm{~g}$ of iron powder were loaded on an area of approximately $1 \mathrm{~cm}^{2}$. When the process was finished, the electrodes were vacuum dried for another day to ensure consistency.

In our previous investigations regarding the role of selected electrode additives (such as potassium sulphide, bismuth sulphide, elemental bismuth and iron sulphide) in the performance of the iron electrode [6,17], we have found that although the soluble bisulphite anion is responsible for an enhancement of cell performance, potassium sulphide only marginally improves the overall efficiency of the NiFe cell. This experimental observation seems rather counterintuitive. However, we now believe the amounts of potassium sulphide that we used then, are in fact very low to be significant, and it should be investigated at larger compositions. This can only be achieved by using it as an electrolyte component. Moreover, the role of lithium hydroxide as an electrolyte additive is not fully understood, it has been suggested its presence would enhance the working life of the battery. Therefore, it usually encounters with most NiFe electrolyte systems at a concentration close to $0.1 \mathrm{M}$. However, not much has been said about its role in enhancing the performance of the battery. With this in mind, we decided to investigate electrolyte systems for $\mathrm{NiFe}$ cells, using lithium hydroxide and potassium sulphide at a constant composition of $0.1 \mathrm{M}$ each, for otherwise, the number of experiments would be literally unmanageable. The role of these additives is not going to be considered for the present study. The specifications of the chemicals and materials used to produce the electrolyte solutions were as follows:

- Potassium hydroxide (purity $\geq 85.0 \%$, pellets) from Sigma Aldrich

- Lithium hydroxide (purity $\geq 98.0 \%$ ) from Sigma Aldrich

- Potassium sulphide (purity $\geq 99.5 \%$ ) from Sigma Aldrich

- Deionized water
In-house deionized water was produced by using an Elix 10-Milli-Q Plus water purification system (Millipore, Eschborn, Germany). By keeping the concentration of PTFE constant to a value of $10 \%$ and using the mixing rules in a three-dimensional concentration space and expressing the compositions on a PTFE-free basis, it is possible to reduce the dimensionality of the system and consider it as a binary system. Electrode formulations based upon Table 1 were produced.

In-house-produced $\mathrm{Fe} / \mathrm{FeS}$ electrodes were tested in a three-electrode cell. Nickel electrodes, (pocket design, $1.4 \times 8.5 \mathrm{~cm})$, obtained from a commercial nickel iron battery (Sichuan Changhong Battery Co.), were used as the positive terminal of the cell. All potentials were measured against a mercury/mercury oxide $(\mathrm{Hg} / \mathrm{HgO})$ reference electrode $\left(\mathrm{E}_{\mathrm{H}_{3} / \mathrm{H}_{\mathrm{S}} \mathrm{O}}^{0}=+0.098 \mathrm{~V}\right.$ vs. NHE). Experiments of charge and discharge were performed on a 64-channel Arbin SCTS. Figure 1 provides a sketch of the cell test configuration.

Experiments of charge and discharge were conducted under galvanostatic conditions at room temperature until the steady state was reached. Cells were cycled from 0.6 to $1.4 \mathrm{~V}$ versus $\mathrm{Hg} / \mathrm{HgO}$ at a $\mathrm{C} / 5$ rate. Formation and stabilization of the electrodes were found to be complete by the 30 th cycle of charge and discharge $[6,17]$.

Cyclic voltammetry was conducted on an 8-channel Solartron $1470 \mathrm{E} / 1455 \mathrm{~A}$ potentiostat/galvanostat with frequency response analyzers. The electrochemical measurements were made using a conventional three-electrode glass cell. Measurements were carried out at room temperature $\left(25^{\circ} \mathrm{C}\right)$ using a $\mathrm{Hg} / \mathrm{HgO}$ reference electrode and a platinum wire as a counter electrode in an aqueous solution of $5.1 \mathrm{M} \mathrm{KOH}+0.3 \mathrm{M} \mathrm{LiOH}+0.44 \mathrm{M} \quad \mathrm{K}_{2} \mathrm{~S}$ as electrolyte.

ATR-FTIR spectroscopy was used to investigate the surface chemistry of iron electrodes before and after cycling using a Bruker Alpha FTIR spectrometer with a Diamond crystal $\left(400-4000 \mathrm{~cm}^{-1}\right)$.

Phase constitution was undertaken by XRD on a Bruker D2-Phaser, with $\mathrm{Cu}-\mathrm{K} \alpha 1$ radiation $(\lambda=1.5406 \mathrm{~nm})$. The $2 \theta$ angular region from between $15^{\circ}$ and $85^{\circ}$ was explored at a constant scan rate $\left(1 \mathrm{~min}^{-1}\right)$, with a step size of 0.1 and increment of 0.02 ; the detector was set to $0.27 \mathrm{~V}$ of the lower detection limit.
Table 1 Experimental conditions (compositions on a PTFEfree basis)

\begin{tabular}{lcc}
\hline Factor & Low (\%) & High (\%) \\
\hline $\mathrm{Fe}$ & 0 & 50 \\
$\mathrm{FeS}$ & 50 & 100 \\
\hline
\end{tabular}




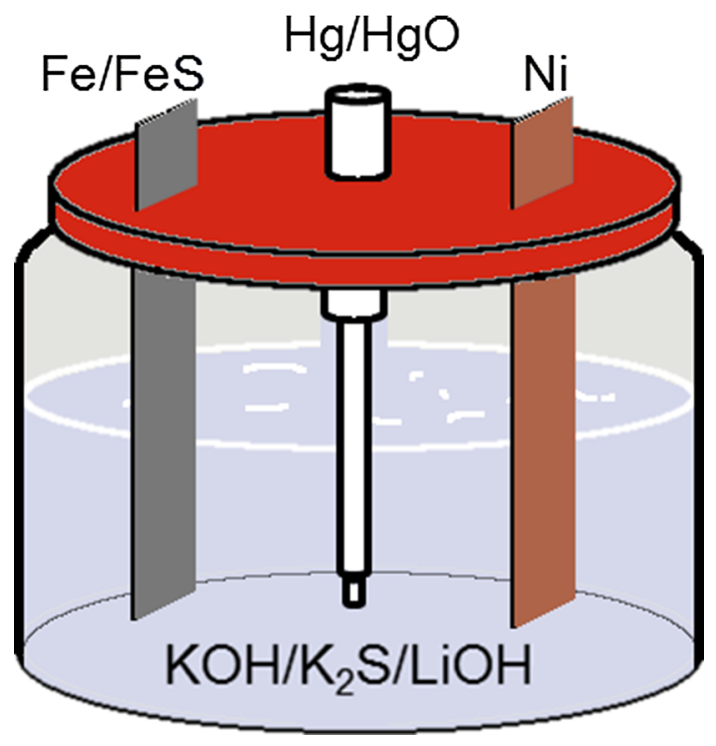

Fig. 1 Test cell configuration

\section{Results and discussion}

It has been long established that any $\mathrm{NiFe}$ cell requires a relatively long conditioning period (in the order of 30 cycles of charge/discharge) before it reaches the steady state. Figures 2, 3 and 4 confirm the existence of such a conditioning period, which is required for any $\mathrm{NiFe}$ cell to achieve their true performance. Basically, the performance of any battery increases from nearly zero (early cycles of charge-discharge) up to $96 \%$ after the steady state was reached.

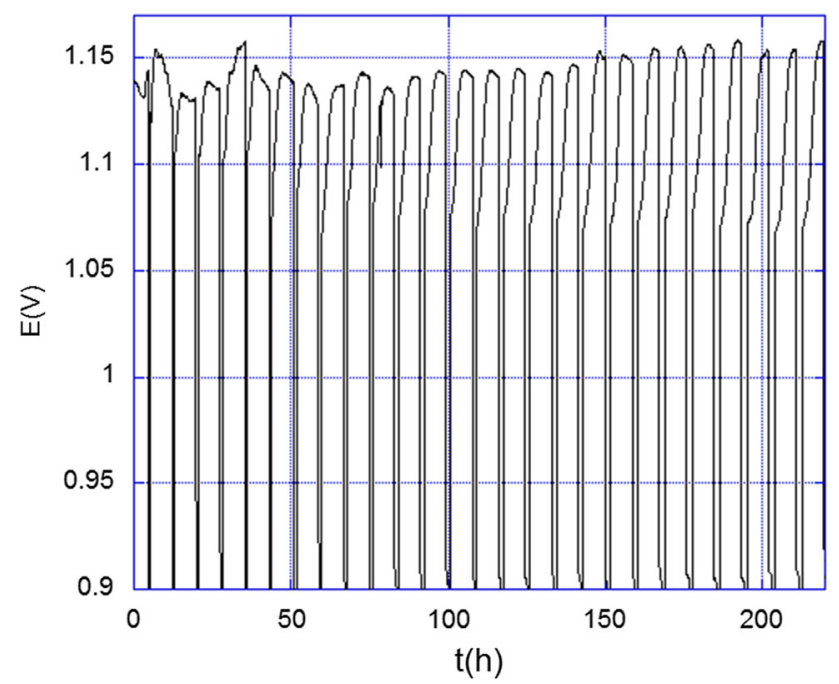

Fig. 2 Charge and discharge profile for an $80 \% \mathrm{FeS}+20 \% \mathrm{Fe}$ electrode versus mercury/mercury oxide $(\mathrm{Hg} / \mathrm{HgO})$ reference electrode

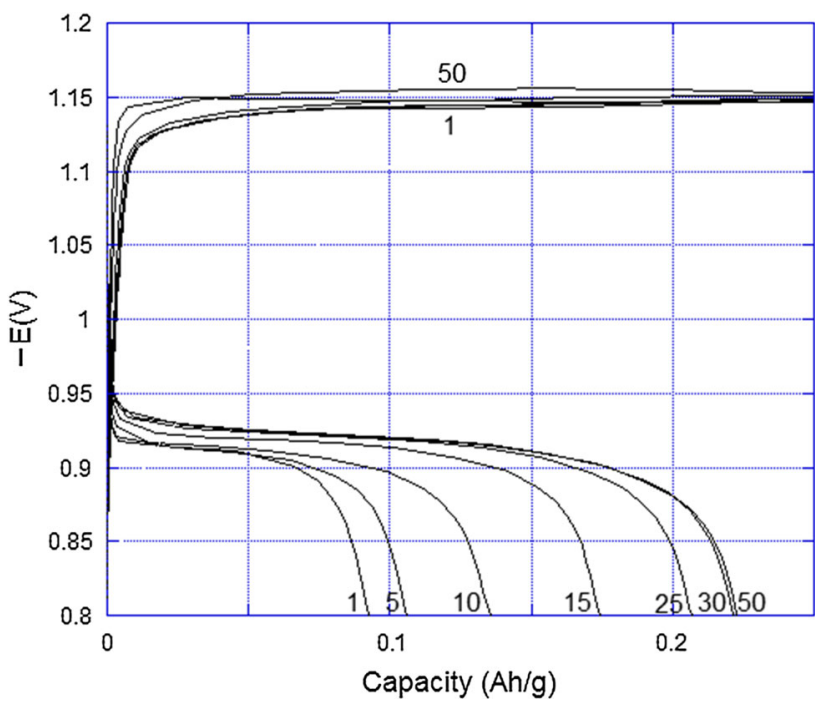

Fig. 3 Selected charge and discharge curves for the $80 \%$ $\mathrm{FeS}+20 \% \mathrm{Fe}$ electrode formulation versus mercury/mercury oxide $(\mathrm{Hg} / \mathrm{HgO})$ reference electrode. The upper curves represent the charging of the electrode; likewise, the lower curves represent the discharging of the electrode

Unfortunately, iron-based electrodes utilizing large amounts of iron sulphide (above $70 \%$ ) exhibit a much reduced life cycle when compared to their low iron sulphide content counterparts. Broadly speaking, high iron sulphide-based anodes would last for no more than 60-70 cycles of charge and discharge (results not shown). The authors believe this is probably due to the solubility and/or electrochemical stability of iron sulphide.

Figure 3 indicates that cells reach the steady state after then 30th cycle. In addition, a specific charge storage capacity close to $0.22 \mathrm{Ah} \mathrm{g}^{-1}$ was observed. Although larger capacities (close to $0.8 \mathrm{Ah} \mathrm{g}^{-1}$ ) have been reported by nano-structuring the electrode [11, 18-20], our manufacturing process is relatively simple and utilizes commercial grade reactants, which makes it ideal for largescale energy storage applications.

As shown in Fig. 5, the larger the amount of iron sulphide the higher the performance of the electrode (in terms of coulombic efficiency). The nature of the association between the variables was of the form given by Eq. (3).

$\eta_{Q}=51.4106+0.4496 \% \mathrm{FeS}$

Coulombic efficiency was explained by the factor treatment (iron sulphide content in the iron electrode). The linear model is not only significant (F-statistic $=677.6)$ but it also exhibits a good correlation (Pearson's coefficient of correlation $\left.r^{2}=0.9064\right)$. This conclusion seems to indicate that the active material within the electrode is basically iron sulphide. However, as we reported in our previous publication [16], at low concentrations of iron sulphide (up to $20 \%$ ) the performance of the iron electrode 
increases with the FeS content until $11 \%$, then it goes down. Moreover, at large compositions of $\mathrm{FeS}$ there are formulations that exhibit no significant differences between them, consider for example formulations based upon 60 and 70 or 90 and $100 \% \mathrm{FeS}$.

Following a similar approach, the utilization of electroactive material was explained by the factor composition of iron sulphide. Unlike with coulombic efficiency, the only significant term is the intercept (for either first or second order model), which suggests that the mean (given by the independent term) could be considered representative of the entire data set, and therefore, in terms of utilization of electroactive material, no meaningful differences across formulations were found. This behaviour is depicted in Fig. 6.

Table 2 reports coulombic efficiency for the cells used during the testing; likewise, Table 3 lists experimental values of coulombic efficiency and utilization of electroactive material for our in-house-made electrodes. As can be seen, the data exhibit large variability so a relatively large number of replicates (12 in this case) were required to increase the statistical reliability of the analysis. With this in mind, any sample whose coulombic efficiency or utilization of electroactive material lays more than two standard deviations from the mean was rejected.

Figure 7 shows the $600-5000 \mathrm{~cm}^{-1}$ ATR-FTIR spectra for our electrodes after 50 cycles of charge and discharge. Basically, the spectra include a signal near $660 \mathrm{~cm}^{-1}$ corresponding to either $\mathrm{Fe}-\mathrm{S}$ or $\mathrm{Fe}-\mathrm{O}$ stretching; a weak signal appearing near $930 \mathrm{~cm}^{-1}$ corresponding to $\mathrm{Fe}-\mathrm{OH}$ stretching; a very broad peak appearing at $3300 \mathrm{~cm}^{-1}$ corresponding to $\mathrm{OH}$ stretching was also found; however, this last peak could be due to some adsorbed water

Table 2 Cell performance (coulombic efficiency, 50th cycle)

\begin{tabular}{clllll}
\hline 50 & 60 & 70 & 80 & 90 & 100 \\
\hline FeS $\%$ & & & & & \\
71.6 & 80.1 & 81.5 & 92.3 & 98.8 & 95.9 \\
74.7 & 81.2 & 79.9 & 86.5 & 92.2 & 92.5 \\
73.6 & 81.1 & 78.8 & 90.4 & 95.2 & 93.3 \\
70.1 & 80.8 & 80.0 & 91.6 & 94.3 & 96.1 \\
74.2 & 78.4 & 81.8 & 85.4 & 92.4 & 94.9 \\
70.7 & 78.3 & 81.0 & 85.6 & 92.6 & 94.8 \\
74.3 & 78.3 & 85.3 & 86.1 & 91.7 & 92.7 \\
71.5 & 82.2 & 85.2 & 85.3 & 92.2 & 94.8 \\
69.2 & 81.0 & 84.7 & 87.1 & 93.0 & 94.5 \\
72.3 & 81.5 & 81.0 & 87.8 & 96.9 & 97.8 \\
73.0 & 80.6 & 81.5 & 88.8 & 92.4 & 96.5 \\
74.9 & 77.4 & 81.6 & 90.5 & 92.4 & 90.9 \\
\hline
\end{tabular}

Table 3 Experimental design matrix and results (for the 50th cycle)

\begin{tabular}{llr}
\hline FeS $\%$ & $\eta_{\mathrm{Q}}(\exp )$ & \multicolumn{1}{c}{$u_{\mathrm{Q}}(\exp )$} \\
\hline 50 & $72.5 \pm 2.9$ & $8.3 \pm 2.3$ \\
60 & $80.1 \pm 2.4$ & $9.8 \pm 2.8$ \\
70 & $81.9 \pm 3.3$ & $10.5 \pm 2.7$ \\
80 & $88.1 \pm 3.5$ & $10.4 \pm 3.7$ \\
90 & $93.6 \pm 3.6$ & $11.6 \pm 4.1$ \\
100 & $94.5 \pm 3.5$ & $10.8 \pm 2.6$ \\
\hline
\end{tabular}

molecules or some remaining potassium or lithium hydroxide (coming from the electrolyte).

Similar results were obtained for all electrode formulations and therefore, the results are not shown. It is important to mention that we noticed the existence of a correlation between the intensity of the $\mathrm{Fe}-\mathrm{S}$ bands at 1100 and $1700 \mathrm{~cm}^{-1}$ and the performance of the cell. However, we already know that the larger the FeS content the better the performance of the battery, therefore infrared analysis confirms our experimental results. It would be interesting to explore the UV/Vis region of the electromagnetic spectrum to consolidate these findings, and is proposed as a future work.

The XRD analysis of the electrodes indicates there are no meaningful differences across formulations. We believe that this is because during the charge of the electrode, the different electrode formulations $(50-100 \% \mathrm{FeS})$ would render the same active functional groups that we believe should be based on either $\mathrm{Fe}(0), \mathrm{F}(\mathrm{I}), \mathrm{Fe}(\mathrm{II})$ or even $\mathrm{Fe}(\mathrm{III})$. After this process is finished (first 20-25 cycles of charge and discharge), the anode would behave in the same way as if they were traditional iron-based electrodes under strong alkaline conditions. These ideas are supported in part by the long-run performance of batteries. (Note how formulations based on 90-100\% FeS exhibit no meaningful differences, as shown in Figs. 4, 5 and 6).

Furthermore, the utilization of the electroactive material is relatively low, so it follows that there is a large amount of iron or iron sulphide that does not participate in the electrochemical process and it dominates the entire XRD spectrum ( $\mathrm{Fe}$ and $\mathrm{FeS}$ signals). Figure 8 shows a typical XRD trace of one of our electrodes after 50 cycles of charge and discharge. This figure confirms the presence of $\alpha$-Fe but we have not found any evidence of other polymorphs of iron (neither $\beta$-Fe nor $\gamma$-Fe); however, we had found a very weak signal at $2 \theta=24^{\circ}$ corresponding to either $\alpha-\mathrm{Fe}_{2} \mathrm{O}_{3}$ or $\mathrm{Fe}(\mathrm{OH})_{2}$.

Although we have found no compelling evidence of any form of iron oxyhydroxide in our samples, it has been proposed that under alkaline conditions, $\mathrm{Fe}(\mathrm{III})$ could transform into $\beta-\mathrm{FeOOH}$ and then to $\alpha-\mathrm{Fe}_{2} \mathrm{O}_{3}$. In fact, the passive film on iron would consist of many different forms 


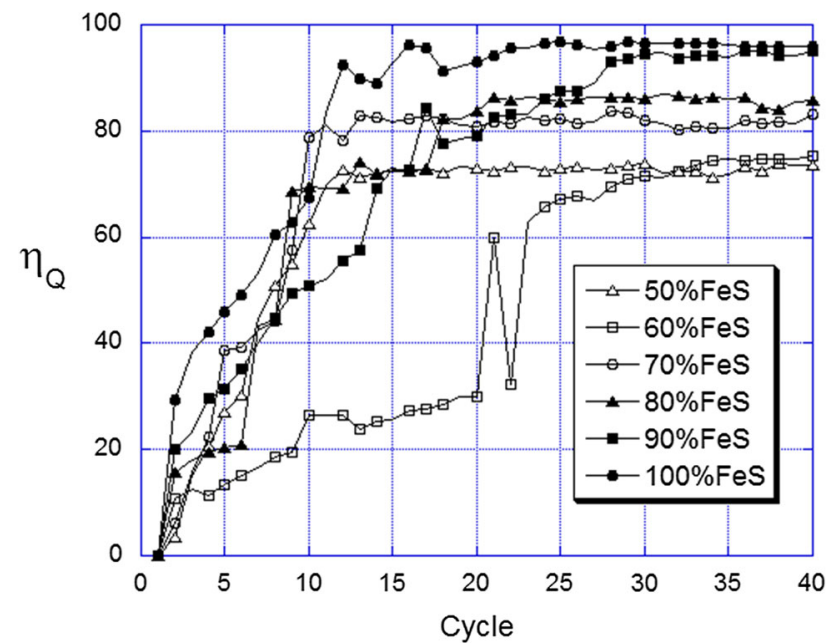

Fig. 4 Coulombic efficiency versus cycle number for selected electrolyte systems

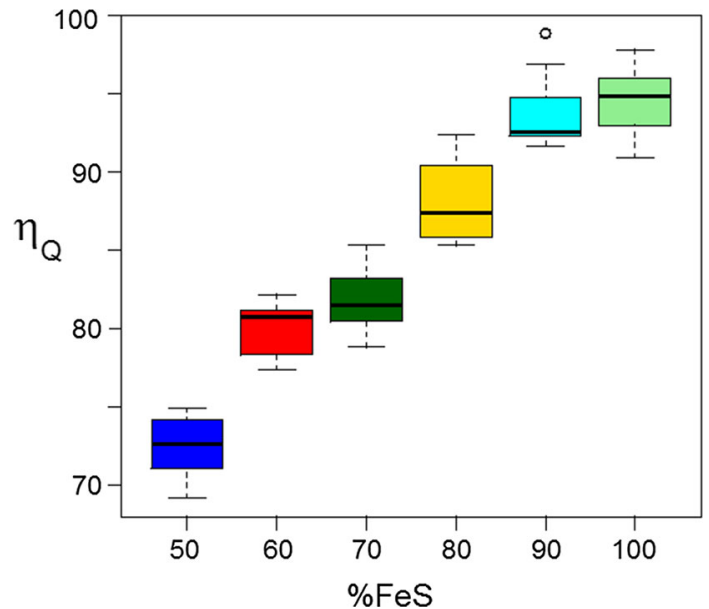

Fig. 5 Coulombic efficiency $\left(\eta_{\mathrm{Q}}\right)$ versus iron sulphide content for selected electrolyte systems (50th cycle)

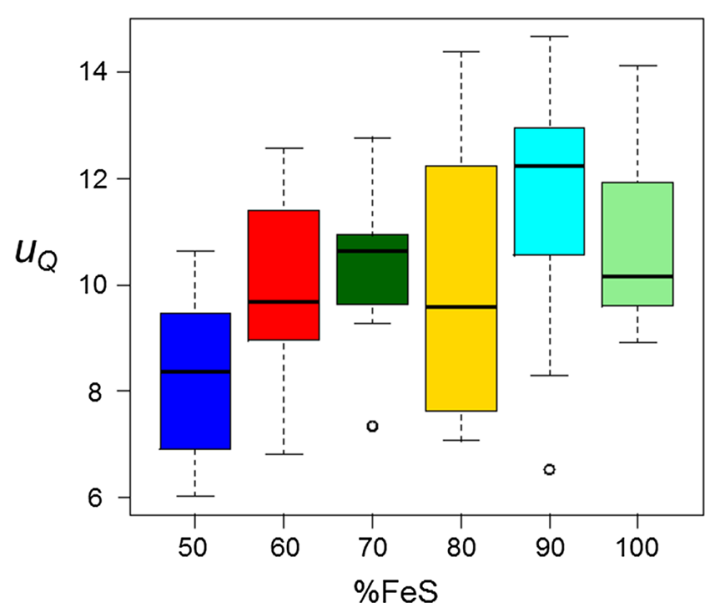

Fig. 6 Utilization of electroactive material $\left(\mathrm{u}_{\mathrm{Q}}\right)$ versus iron sulphide content for selected electrolyte systems (50th cycle)

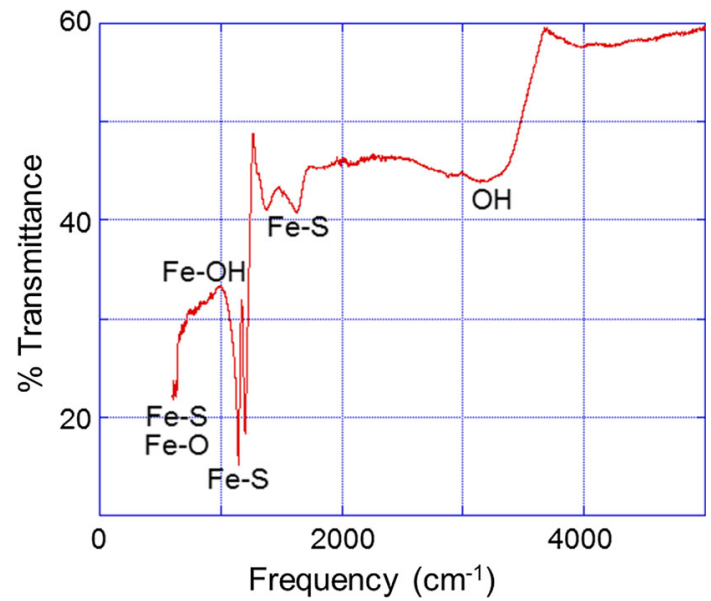

Fig. 7 ATR-FTIR spectra $\left(600-5000 \mathrm{~cm}^{-1}\right)$ of $80 \% \mathrm{FeS}+20 \% \mathrm{Fe}$ based electrode

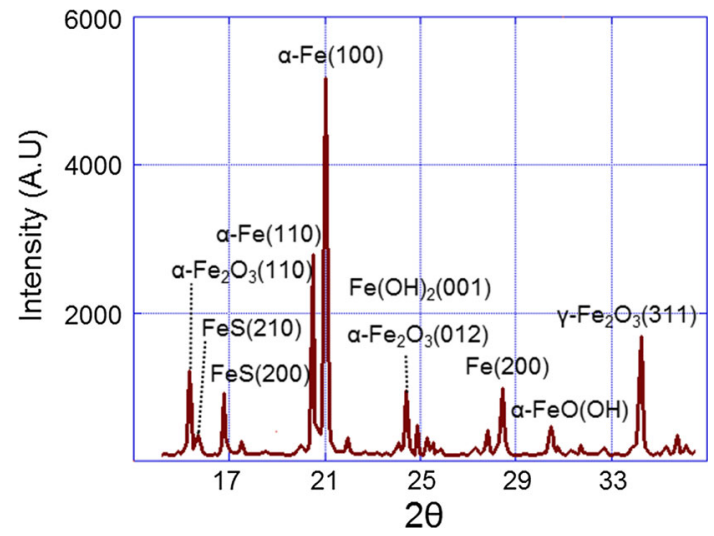

Fig. 8 XRD for iron electrode after being cycled 50 times with electrode formulation $80 \% \mathrm{FeS}+20 \% \mathrm{Fe}$

of iron such as magnetite, maghemite, among others [21]. Moreover, either goethite $(\alpha-\mathrm{FeOOH})$ or akaganeite $(\beta$ $\mathrm{FeOOH}$ ) can transform into $\alpha-\mathrm{Fe}_{2} \mathrm{O}_{3}$ [21-23], which means that the signal appearing at $2 \theta=24^{\circ}$ (Fig. 7) could very well be due to either of those species after transforming into $\alpha-\mathrm{Fe}_{2} \mathrm{O}_{3}$. However, this very same signal could be related with $\mathrm{Fe}(\mathrm{OH})_{2}$, which can be oxidized into either magnetite $\left(\mathrm{Fe}_{3} \mathrm{O}_{4}\right)$, goethite, akaganeite or lepidocrocite $(\gamma$ $\mathrm{FeOOH}$ ) [24], which in turn could also transform into $\alpha$ $\mathrm{Fe}_{2} \mathrm{O}_{3}$. Magnetite can also undergo transformation into $\gamma$ $\mathrm{Fe}_{2} \mathrm{O}_{3}$ and then into $\alpha-\mathrm{Fe}_{2} \mathrm{O}_{3}$ [25]. Finally, evidence of iron hydroxide and oxyhydroxide was noted, as well as indications of reaction of the iron electrode with the solvent (signal corresponding to $\mathrm{KFeS}_{2}$ appearing at $2 \theta=27^{\circ}$ ).

Our experimental results seem to suggest that battery performance is enhanced by the presence of potassium sulphide in the electrolyte. The authors believe a heterogeneous reaction between the electrode and the electrolyte 
might be possible. The XRD evidence of functional groups of the form $\mathrm{Fe}-\mathrm{S}$ was found on all samples.

Based upon our experimental results and utilizing the reactions suggested for the formation of $\mathrm{Na}-\mathrm{S}$ species, we would suggest that reactions between the electrode and electrolyte prior to the charge/discharge process of the cell might happen. These reactions presuppose that potassium ions from the electrolyte must be reduced before the reaction would proceed:

$$
\begin{aligned}
& 4 \mathrm{~K}+3 \mathrm{FeS}_{2} \rightarrow 2 \mathrm{~K}_{2} \mathrm{~S}_{3}+3 \mathrm{Fe} \\
& 2 \mathrm{~K}+\mathrm{FeS}_{2} \rightarrow 2 \mathrm{~K}_{2} \mathrm{~S}_{2}+3 \mathrm{Fe} \\
& 4 \mathrm{~K}+\mathrm{FeS}_{2} \rightarrow 2 \mathrm{~K}_{2} \mathrm{~S}+\mathrm{Fe} .
\end{aligned}
$$

Although no evidence of reactions between lithium and sulphur was found, similar reactions can be proposed (less likely).

$$
\begin{aligned}
& 4 \mathrm{Li}+3 \mathrm{FeS}_{2} \rightarrow \mathrm{Li}_{4} \mathrm{Fe}_{2} \mathrm{~S}_{5}+\mathrm{FeS} \\
& 2 \mathrm{Li}+\mathrm{Li}_{4} \mathrm{Fe}_{2} \mathrm{~S}_{5}+\mathrm{FeS} \rightarrow 3 \mathrm{Li}_{2} \mathrm{FeS}_{2} \\
& 6 \mathrm{Li}+3 \mathrm{Li}_{2} \mathrm{FeS}_{2} \rightarrow 6 \mathrm{Li}_{2} \mathrm{~S}+3 \mathrm{Fe} \\
& 2 \mathrm{Li}+\mathrm{FeS} \rightarrow \mathrm{Li}_{2} \mathrm{~S}+\mathrm{Fe}
\end{aligned}
$$

In order to investigate the electrochemical properties of the cell, cyclic voltammetry experiments were conducted under conditions that maximize coulombic efficiency; this is $5.1 \mathrm{M} \mathrm{KOH}+0.44 \mathrm{M} \mathrm{K}_{2} \mathrm{~S}+0.3 \mathrm{M} \mathrm{LiOH}$. Figure 9 shows a typical cyclic voltammetry experiment conducted with one of our electrode formulations.

As shown in Fig. 9, peaks appearing between -0.5 and $-1.1 \mathrm{~V}$ (vs. SCE) would correspond to the oxidation of

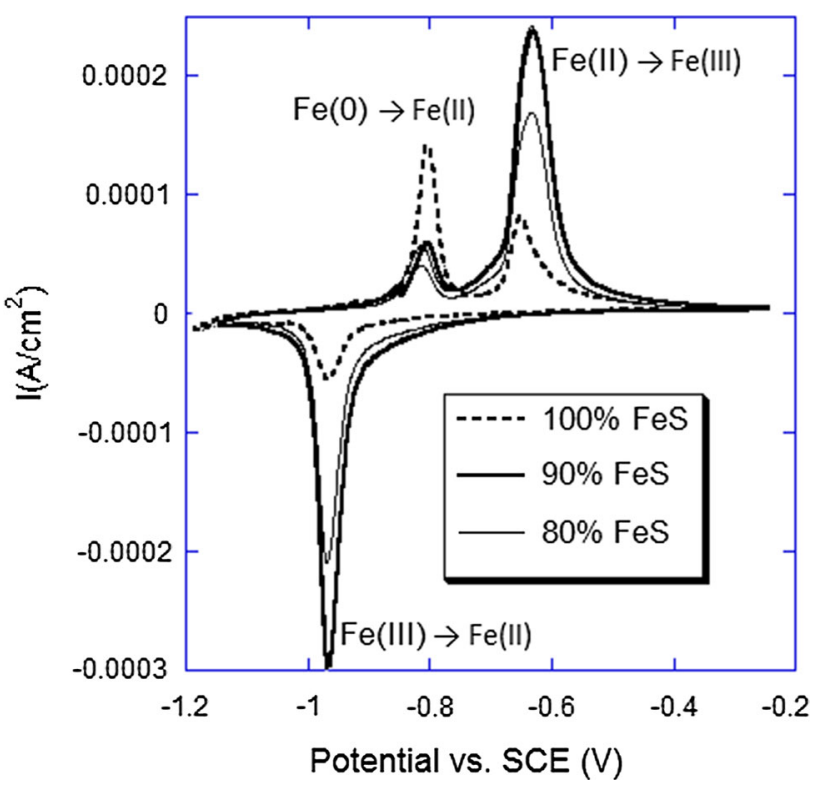

Fig. 9 Triangular sweep voltammetry curves for iron sulphide-based anode formulations. The curves correspond to $\mathrm{CV}$ experiments performed in $5.1 \mathrm{M} \mathrm{KOH}$ solution at a scan rate of $0.5 \mathrm{mV} \mathrm{s}^{-1}$
$\mathrm{Fe}(0)$ to $\mathrm{Fe}(\mathrm{II})$ and $\mathrm{Fe}(\mathrm{II})$ to $\mathrm{Fe}(\mathrm{III})$. Likewise, a curvature change appearing near $-1.4 \mathrm{~V}$ was identified and believed to correspond to the reduction of $\mathrm{Fe}(\mathrm{II})$ to $\mathrm{Fe}(0)$. Finally a peak located near $-0.7 \mathrm{~V}$ was also found and believed to correspond to the reduction of $\mathrm{Fe}$ (III) to $\mathrm{Fe}(\mathrm{II})$.

It has been proposed that sulphur-containing species such as iron sulphide could improve the performance of a $\mathrm{NiFe}$ cell by controlling the corrosion state of the iron electrode [26-28]; however, the detailed mechanism is not fully understood [29].

It has been reported that hydrogen can enter into transition metals such as iron, and that this process is favoured by the presence of sulphur-containing compounds [30, 31]. It has also been reported that species such as $\mathrm{HS}^{-}, \mathrm{S}^{2-}$, and $\mathrm{H}_{2} \mathrm{~S}$ are common promoters of hydrogen ingress into iron [31]. Therefore, it necessarily follows that iron electrodes produced at large concentrations of iron sulphide should exhibit, and indeed they do, better charge and discharge properties than their low concentration counterparts.

It has been reported that hydrogen evolution and ingress into iron is strongly enhanced by renewal of the metal surface [32]. Figures 2 and 3 confirm that the performance of the $\mathrm{Fe} / \mathrm{FeS}$ electrodes will increase with the cycling number, until steady state conditions are reached.

The adsorption of soluble $\mathrm{HS}^{-}$(coming from the added potassium sulphide) can be rationalized as an electrosorptive process with charge transfer as illustrated by Eq. (11) [32-34]:

$\mathrm{M}+\mathrm{HS}_{s \ln }^{-} \rightarrow M\left(\mathrm{HS}^{-}\right) \rightarrow \mathrm{MS}_{\mathrm{ads}}+2 e(\mathrm{M})+\mathrm{H}_{s \ln }^{+}$.

Therefore, any hydrogen that is produced through Eq. (11) would be neutralized by the alkaline medium, so the reaction would be displaced to the right (Le Châtelier's principle). Similarly the mechanism represented by Eq. (12) would also occur:

$\mathrm{M}+\mathrm{KS}_{s \ln }^{-} \rightarrow \mathrm{M}\left(\mathrm{KS}^{-}\right) \rightarrow \mathrm{MS}_{\mathrm{ads}}+2 e(\mathrm{M})+\mathrm{K}_{s \ln }^{+}$.

Basically, the newly formed $\mathrm{MS}_{\mathrm{ads}}$ species will promote the ingress of hydrogen into the electrode as suggested by Eq. (13)

$\mathrm{MS}_{\mathrm{ads}}+\mathrm{H}_{2} \mathrm{O}+3 e(\mathrm{M}) \rightarrow \mathrm{MH}_{\mathrm{ads}}+\mathrm{HS}_{s \ln }^{-}+2 \mathrm{OH}^{-}$.

A close look at Eq. (13) reveals that during hydrogen ingress into the iron electrode, both $\mathrm{HS}^{-}$and $\mathrm{OH}^{-}$left the electrode thus regenerating the electrolyte.

Finally, the authors believe that a combined effect between the presence of sulphur species, not only in the electrolyte but in the electrode itself, and the degradation of the electrode that occurs during the conditioning period are key to understand the reactivity of the iron electrode. These ideas are supported in part by observations that have been made during the evolution of hydrogen under alkaline conditions [33]. 


\section{Conclusions}

By pursuing the development of cost effective energy storage solutions, we have achieved $\mathrm{NiFe}$ cells that produce coulombic efficiencies over $96 \%$. The utilization of electroactive material values close to $12 \%$ and capacities in the order of $220 \mathrm{mAh} \mathrm{g}^{-1}$. These results are very promising as we have used neither ultra-pure reactants, nor we have nano-structured the electrode.

Our results suggest there is no clear trend between the composition of the electrode and the utilization of electroactive material. It is our belief that the utilization of electroactive material is related to the manufacturing process and more work is still necessary to clarify this problem.

A strong linear association between electrode performance and iron sulphide content was found. It is our belief that this association would indicate the active centres for the charge/discharge process of the cell, which are precisely $\mathrm{Fe}-\mathrm{S}$ functional groups. The infrared analysis suggests the existence of a relationship between the performance of the battery and the presence of $\mathrm{Fe}-\mathrm{S}$ bonds.

It is thought that battery performance is enhanced by the presence of potassium sulphide in the electrolyte. The reaction between the electrolyte (essentially $\mathrm{KOH}$ ) with the electrode would foment the charge/discharge efficiency of the battery. The XRD results support the existence of functional groups of the form $\mathrm{Fe}-\mathrm{S}$.

A conditioning period was found to be necessary for the cells to reach the steady state. This period consists of approximately 30 cycles of charge and discharge. Similar behaviour has been found not only with low concentration FeS-based electrodes, but with most iron-based anodes for $\mathrm{NiFe}$ cells.

The improvement in coulombic efficiency and elimination of the hydrogen-producing side reaction may have important implications for the commercial development of this battery type.

Acknowledgments The authors would like to acknowledge the U.K. Engineering and Physical Sciences Research Council for supporting this work (EP/K000292/1; SPECIFIC Tranche 1: Buildings as Power Stations).

Open Access This article is distributed under the terms of the Creative Commons Attribution 4.0 International License (http://crea tivecommons.org/licenses/by/4.0/), which permits unrestricted use, distribution, and reproduction in any medium, provided you give appropriate credit to the original author(s) and the source, provide a link to the Creative Commons license, and indicate if changes were made.

\section{References}

1. Gao P, Liu Y, Lv W, Zhang R, Liu W, Bu X, Li G, Lei L (2014) J Power Sources 265:192-200

2. Chaurey A, Deambi S (1992) Renew Energy 2:227-235

3. Halpert G (1984) J Power Sources 12:177-192

4. Shukla AK, Venugopalan S, Hariprakash B (2001) J Power Sources 100:125-148

5. Manohar AK, Yang C, Malkhandi S, Yang B, Prakash GKS, Narayanan SR (2012) J Electrochem Soc 159:A2148-A2155

6. Posada JOG, Hall PJ (2014) J Power Sources 262:263-269

7. Manohar AK, Yang C, Malkhandi S, Prakash GKS, Narayanan SR (2013) J Electrochem Soc 160:A2078-A2084

8. Malkhandi S, Yang B, Manohar AK, Prakash GKS, Narayanan SR (2012) J Am Chem Soc 135:347-353

9. Mackenzie MJ Jr, Salkind AJ (1969) US Patent 3,484,291 A

10. Posada JOG, Hall PJ (2015) J Electrochem Soc 162:A2036A2043

11. Wang H, Liang Y, Gong M, Li Y, Chang W, Mefford T, Zhou J, Wang J, Regier T, Wei F, Dai H (2012) Nat Commun 3:197

12. Manohar AK, Malkhandi S, Yang B, Yang C, Prakash GKS, Narayanan SR (2012) J Electrochem Soc 159:A1209-A1214

13. R.G. Ogg, P.Bennett, A Seidel, P Gifford. In Google Patents 2014

14. DT Van, FM Mulder. In Google Patents 2014

15. Shangguan E, Li F, Li J, Chang Z, Li Q, Yuan X-Z, Wang H (2015) J Power Sources 291:29-39

16. Posada JOG, Hall PJ (2015) Sustain Energy Technol Assess 11:194-197

17. Posada JOG, Hall PJ (2014) J Power Sources 268:810-815

18. Periasamy P, Babu BR, Iyer SV (1996) J Power Sources 62:9-14

19. Liu Z, Tay SW, Li X (2011) Chem Commun 47:12473-12475

20. Ravikumar MK, Balasubramanian TS, Shukla AK (1995) J Power Sources 56:209-212

21. Shao HB, Wang JM, He WC, Zhang JQ, Cao CN (2005) Electrochem Commun 7:1429-1433

22. Cao H, Wang G, Zhang L, Liang Y, Zhang S, Zhang X (2006) ChemPhysChem 7:1897-1901

23. Musić S, Czakó-Nagy I, Salaj-Obelić I, Ljubešić N (1997) Mater Lett 32:301-305

24. Miyamoto H, Shinjo T, Shinjo T, Bando Y, Takada T (1968) Bulletin of the Institute for Chemical Research, Kyoto University 45:333-341

25. Zhao B, Wang Y, Guo H, Wang J, He Y, Jiao Z, Wu M (2007) Mater Sci-Poland 25:1143-1148

26. Jayalakshmi M, Nathira Begum B, Chidambaram VR, Sabapathi R, Muralidharan VS (1992) J Power Sources 39:113-119

27. Lyons MEG, Burke LD (1984) J Electroanal Chem 170:377-381

28. Balasubramanian TS, Shukla AK (1993) J Power Sources 41:99-105

29. Diez-Perez I, Sanz F, Gorostiza P (2006) Electrochem Commun 8:1595-1602

30. Williams G, McMurray HN, Newman RC (2013) Electrochem Commun 27:144-147

31. Flis-Kabulska I, Flis J, Zakroczymski T (2007) Electrochim Acta 52:7158-7165

32. Flis-Kabulska I (2009) Electrochem Commun 11:54-56

33. Solmaz R, Kardaş G (2009) Electrochim Acta 54:3726-3734

34. Qian SY, Conway BE, Jerkiewicz G (1999) Phys Chem Chem Phys 1:2805-2813 